\title{
Current Season Photoassimilate Distribution in Sweet Cherry
}

\author{
Marlene Ayala ${ }^{1}$ \\ Departamento de Fruticultura y Enología, Facultad de Agronomía e Ingeniería Forestal, Pontificia \\ Universidad Católica de Chile, Santiago 78204360, Chile \\ Gregory Lang \\ Department of Horticulture, Michigan State University, Plant and Soil Sciences Building, 1066 Bogue \\ Street, East Lansing, MI 48824
}

\begin{abstract}
Additional IndeX words. fruit development, leaf area, partitioning, Prunus avium, sink-source, stage III, ${ }^{13} \mathrm{C}$
Abstract. Sweet cherry (Prunus avium) tree canopies comprise three types of leaf populations: fruiting spur (FS), nonfruiting spur (NFS), and extension shoot (ES) leaves. The contribution of each leaf population as sources of photoassimilate synthesis and distribution for sweet cherry fruit development has not been described previously. To determine how carbon fixed by different leaf populations is distributed to reproductive and vegetative sinks during fruit development, fruiting branches of 7-year-old 'Ulster' sweet cherry trees grown on 'Gisela ${ }^{\circledR}$ ' (Gi6) (Prunus cerasus $\times$ Prunus canescens) rootstock at Michigan State University's Clarksville Research Center (Clarksville, MI) were exposed to ${ }^{13} \mathrm{CO}_{2}$ labeling on five dates in 2003 [25, 40, 44, 56, and 75 days after full bloom (DAFB), which occurred on 30 Apr.], comprising the period from late Stage I (SI) to late Stage III (SIII) of fruit development. Fortyeight hours after labeling, whole branches were removed and separated into different organs for ${ }^{13} \mathrm{C}$ analysis by gas chromatography-mass spectrometry (GC-MS). The organs analyzed included: FS leaves, NFS leaves, ES leaves, fruit, and wood + bark from the segment of the branch corresponding to each leaf population. Relative distribution of $\mathrm{C}$ from each leaf population source to each sink varied during fruit development. Overall, the proportion of ${ }^{13} \mathrm{C}$ recovered in the fruit was highest for the FS leaf population (which included fruit exposure to ${ }^{13} \mathrm{CO}_{2}$ ), followed by the NFS leaves, then ES leaves. From SI to SIII, $\approx 60 \%$ of the ${ }^{13} \mathrm{C}$ recovered in the FS portion of the branch was found in the fruit, except during the exponential growth of fruit in mid-SIII (56 DAFB) when this proportion was nearly $80 \%$. About 30\% of the ${ }^{13} \mathrm{C}$ fixed by NFS leaves was found in the fruit during Stage II (SII) (40 DAFB) and early (44 DAFB) and late (75 DAFB) SIII, with higher proportions at SI (45\% at 25 DAFB) and mid-SIII (70\%). About $25 \%$ of the ${ }^{13} \mathrm{C}$ fixed by ES leaves was found in the fruit during SI, SII, and late SIII, with a lower proportion (17\%) at early SIII when shoot growth was exponential, and a higher proportion (nearly $60 \%$ ) at mid-SIII. The proportion of ${ }^{13} \mathrm{C}$ fixed and translocated to ES growth was minimal from FS and NFS leaves throughout the sampling dates, but that by the ES leaves was significant, peaking at early SIII. The results illustrate the dynamics of $C$ contribution from each leaf population between vegetative and reproductive sinks during growth in sweet cherry orchards, which provides useful physiological information for canopy pruning and crop load regulation.
\end{abstract}

In most tree fruit, carbon for fruit and canopy structural growth is provided initially by storage pools, transitioning to current assimilates as leaves become photosynthetically competent (Corelli-Grappadelli et al., 1994; Roper et al., 1988; Teng et al., 2001, 2002; Wünsche et al., 2005). In sweet cherry, reproductive and vegetative growth occurs simultaneously during spring and early summer (Roper et al., 1987). FS and NFS leaf area (LA) is derived from preformed vegetative meristems and reaches a maximum within 3-4 weeks of budbreak (Lang, 2005). However, on well-managed trees, ES LA continues developing from budbreak through harvest, transitioning from preformed to neoformed vegetative meristem activity and leaf expansion. Actively growing aerial sinks (i.e., flowers, fruit, spurs, and ES) compete for the $\mathrm{C}$ provided by these different leaf populations (Ayala and Lang, 2008; Roper et al., 1988). Roper et al. (1987) suggested that import of photoassimilates synthesized by leaves distal to FSs may be

Received for publication 22 Sept. 2017. Accepted for publication 31 Jan. 2018. The research reported was funded in part by a grant from the Michigan Cherry Committee, and supported by Michigan Sate University's AgBioResearch, the USDA National Institute of Food and Agriculture's Hatch projects MICL02002 and MICL01305, and Pontificia Universidad Católica de Chile.

${ }^{1}$ Corresponding author. E-mail: mayalaz@uc.cl. required for optimal fruit development, and branch girdling and defoliation studies demonstrated negative effects on quality traits when fruit were isolated from the major sources of photoassimilates (Ayala and Lang, 2004).

Fruit trees can be considered as a collection of individual sinks (reproductive and vegetative) that compete with each other (DeJong, 1999; Wright, 1989). The sink demand of an organ and its competitive ability to attract assimilates varies by developmental stage during the season (Fischer et al., 2012; Flore and Layne, 1999; Wright, 1989). The C available to individual organs depends on the supply of photoassimilates from sources (i.e., leaves and storage reserves) and the organ's sink demand (Ayala and Lang, 2015; Basile et al., 2002). Farrar (1996) and Minchin et al. (1997) suggested that the distribution of assimilates is controlled by the entire source-sink pathway in the plant system and is not a property of sinks alone. By contrast, dry weight (DW) partitioning among sinks is regulated by sink development (Li et al., 2015; Marcelis, 1996).

Fruit are major sinks for assimilates (DeJong and Walton, 1989). In Prunus species, fruit development follows a double sigmoidal curve, which is divided into three stages (Berman and DeJong, 1996; Flore, 1994). Following pollination and fruit set, SI is characterized by active cell division and rapid initial fruit growth. SII or "pit hardening" is associated with endocarp 
lignification and slower growth of the pericarp. SIII or "final swell" is a period of rapid fruit growth characterized by mesocarp cell enlargement and DW accumulation. The length of each phenological stage is influenced by the ripening characteristics of the variety, which may vary by up to 8-9 weeks in sweet cherry. The shortest stage of cherry fruit development is SII, and $50 \%$ to $80 \%$ of fruit growth occurs during SIII (Flore, 1994). Roper et al. (1988) suggested that because sweet cherry fruit development occurs during a relatively short timeframe (60-70 d), fruit might be high priority sinks. In peach (Prunus persica) and apple (Malus $\times$ domestica), periods of resource limitation lead to a competition for photoassimilates between reproductive and vegetative organs (Grossman and DeJong, 1995; Pavel and DeJong, 1993; Reyes et al., 2016).

The objective of this study was to determine how $\mathrm{C}$ assimilated by FS, NFS, and ES leaf populations on fruiting sweet cherry branches is distributed to competing sinks. It was hypothesized that the distribution of $\mathrm{C}$ fixed by each leaf population would be differentially influenced by dynamic changes in competing reproductive and vegetative sink demands from fruit set to ripening. The contribution of each leaf population as sources of photoassimilate synthesis and distribution for sweet cherry fruit development has not been described previously.

\section{Materials and Methods}

Plant material and environment. The experiment was conducted at Michigan State University's Clarksville Research Center, Clarksville, MI (lat. $42.8^{\circ} \mathrm{N}$, long. $85.2^{\circ} \mathrm{W}$ ). In 2003, mature ( 7 years old) 'Ulster' sweet cherry trees on Gi6 rootstock were selected for pulse-labeling with ${ }^{13} \mathrm{CO}_{2}$. Two rows of 'Ulster' alternated with two rows of 'Hedelfingen' on 'Gisela ${ }^{\circledR} 5$ ' (Gi5) as the cross-pollen source. The trees were grown in a coarse-loamy, mixed, mesic Typic Hapludalf soil of the Lapeer series, trained to a central leader and had similar height $(3.0 \mathrm{~m})$, trunk cross-sectional area, and canopy LA $(12.8 \pm$ $0.5 \mathrm{~m}^{2}$ ). The trees were planted $2.5 \mathrm{~m}$ within the row (maintained weed-free with herbicide) and $4.6 \mathrm{~m}$ between rows (with grass alleys), and were not pruned or thinned during the experiment. Trees were not protected against rain or birds. Fertilizer, drip irrigation, and plant protection pesticides were applied following standard commercial practices. Growing degree days [GDD (base $4.4^{\circ} \mathrm{C}$ )], a measure of heat accumulation for plant growth, was used to associate phenological stages and developmental rates of fruit, leaves, and shoots from budbreak to the end of SIII. Full bloom (FB) occurred on Apr. 30.

Phenological Characterization before ${ }^{13} \mathrm{CO}_{2}$ PUlsing. Six hundred 2-year-old fruiting branches having similar vigor, crop load, length, and diameter were selected for ${ }^{13} \mathrm{CO}_{2}$ pulselabeling and growth measurements. Morphological measurement range means for the selected branches were: length (97.4-100.8 cm), diameter $(18.1-22.1 \mathrm{~mm})$, number of FS and NFS (12-14), FS and NFS leaf number (4.7-6.0), and fruit number (two to three fruit per spur). Most of the branches were located in the middle to upper sections of the canopy, 1.5-2.5 m above the ground. Terminal ES growth (i.e., length and leaf number) was measured weekly from budbreak until terminal budset for all branches. LA for each experimental branch was estimated by counting the total spur number (FS and NFS) and number of ES nodes before each ${ }^{13} \mathrm{C}$-pulse, and measuring the LA of 15 FS, NFS, and ES using detached leaves and a LA meter
(LI-3100; LI-COR, Lincoln, NE). Leaf area per spur (FS and NFS) ranged from $68.1 \pm 5.3$ to $134.4 \pm 5.2 \mathrm{~cm}^{2}$. Leaf area of ES at terminal budset ranged between $785 \pm 7.3$ and $876 \pm 9.3 \mathrm{~cm}^{2}$.

Twenty fruit (F) per branch were measured for fresh weight [FW (grams)] and DW (grams), diameter (millimeters), and soluble solids content [SSC (percent)]. Thirty FS, NFS, and ES were measured for FW, DW, leaf number, and LA.

Treatments (T) AND ${ }^{13} \mathbf{C}$ Labeling. From the 600-branch population previously characterized, a group of 200 branches were selected randomly for growth measurements, and a group of 400 branches were selected randomly for labeling (or as nonlabeled controls). For each leaf population $(T=3)$ and pulse date $($ Date $=5), 10$ single branch replications $(n=10)$ were used for each sampling date (immediately and $48 \mathrm{~h}$ after pulsing). Branch sections corresponding to FS (leaves plus fruit), NFS (leaves only), and ES (leaves plus new shoot) leaf populations were labeled with short pulses of ${ }^{13} \mathrm{CO}_{2}$ at $25 \mathrm{~d}$ (SI), $40 \mathrm{~d}$ (SII), $44 \mathrm{~d}$ (early SIII), $56 \mathrm{~d}$ (mid-SIII), or $75 \mathrm{~d}$ [late SIII (terminal budset)] DAFB. Each labeling date corresponded to the noted phenological stage during fruit development and was a sunny day with the following mean daily temperatures: SI at $11^{\circ} \mathrm{C}$, SII at $16^{\circ} \mathrm{C}$, early SIII at $18^{\circ} \mathrm{C}$, mid-SIII at $27^{\circ} \mathrm{C}$, and late SIII at $21^{\circ} \mathrm{C}$. There was no rain between pulse date and sampling $48 \mathrm{~h}$ later except following the mid-SIII pulse, which had $2.8 \mathrm{~mm}$ of rain in between pulsing and sampling. Three additional nonlabeled branches were removed at each date to quantify natural ${ }^{13} \mathrm{C}$ abundance in leaves.

For each labeled branch, one complete section (FS leaves plus fruit, NFS leaves, or ES leaves plus new shoot) was enclosed in a transparent polyester film (Mylar ${ }^{\circledR}$; DuPont, Wilmington, DE) balloon chamber of appropriate volume and pulsed for $15-20 \mathrm{~min}$ with ${ }^{13} \mathrm{CO}_{2}$ when assimilation rates were positive, between 1000 and $1200 \mathrm{HR} \cdot{ }^{13} \mathrm{CO}_{2}$ was generated by injecting $80 \%$ lactic acid into a $1-\mathrm{L}$ wash bottle containing barium carbonate (98 atom percent ${ }^{13} \mathrm{C}$ ), and swirling and pumping the bottle to deliver a total of $3.9 \mathrm{mmol}$ of ${ }^{13} \mathrm{CO}_{2}$ into each chamber. The average rate of $\mathrm{CO}_{2}$ uptake for each date was calculated. Photosynthetically active radiation ranged between 1456 and $1835 \mu \mathrm{mol} \cdot \mathrm{m}^{-2} \cdot \mathrm{s}^{-1}$ during ${ }^{13} \mathrm{C}$ labeling. Single leaf gas exchange was measured with an IR gas analyzer (CIRAS-2; PP-Systems, Haverhill, MA) for FS, NFS, and ES leaves on selected branches before and during the pulse-labeling. Net assimilation rate (A) varied between 15.7 and $20.4 \mu \mathrm{mol} \cdot \mathrm{m}^{-2} \cdot \mathrm{s}^{-1}$ $\mathrm{CO}_{2}$ among the three leaf populations and dates.

SAMPLING AND ${ }^{13} \mathrm{C}$ ANALYSIS. Immediately after labeling, three fully expanded leaves were sampled from each leaf type to estimate the initial total ${ }^{13} \mathrm{C}$ fixed by each leaf population. When FS were the labeled population, individual fruit were also sampled to estimate the ${ }^{13} \mathrm{C}$ fixed because of fruit photosynthesis.

At $48 \mathrm{~h}$ after each pulse-labeling, each branch was removed at its base to measure FW and DW of different organs and prepare them for ${ }^{13} \mathrm{C}$ enrichment analysis by GC-MS (20-20 mass spectrometer and ANCA-GSL sample combustion unit; PDZ Europa, Sandbach, UK). The organs analyzed included: FS leaves, NFS leaves, ES leaves, fruit, and wood + bark from the segment of the branch corresponding to each leaf population. Extension shoots were divided further into mature fully expanded leaves, developing leaves, young leaves, and wood. In addition, 10 single fruit from the FS section that had been labeled directly with ${ }^{13} \mathrm{C}$ were divided into pericarp (epicarp + mesocarp) and endocarp. All plant materials were oven-dried at $70{ }^{\circ} \mathrm{C}$ for $72-96 \mathrm{~h}$ and ground using a Wiley mill (20 and 40 
mesh; Thomas Scientific, Swedesboro, NJ). Additional samples were prepared from unlabeled branches for natural abundance calculations. ${ }^{13} \mathrm{C}$ enrichment for different organs was calculated according to Boutton (1991) and Vivin et al. (1996).

Statistical analysis. Analysis of variance was conducted by using PROC MIXED procedures of the SAS statistical analysis program (SAS Institute, Cary, NC). The statistical model for the overall experiment was a three-way factorial design with three factors: leaf type $(T=3)$, date (Date $=5)$, and organ $(O=8)$. As extremely high levels of ${ }^{13} \mathrm{C}$ enrichment were expected in directly labeled leaves, these were not considered for statistical analysis.

\section{Results and Discussion}

\section{Growth and fruiting of 2-year-old branches}

Extension shoot growth on 'Ulster'/Gi6 commenced around $\mathrm{FB}$ and terminal budset occurred at 75 DAFB, with an average length of $34 \mathrm{~cm}$ and 19 leaves per ES (Table 1), and six leaves per spur (FS or NFS). Mean LA per spur was $\approx 10 \%$ larger for NFS compared with FS [129 vs. $118 \mathrm{~cm}^{2}$ (data not shown)]. Mean area per leaf was greatest for ES leaves $\left(44 \mathrm{~cm}^{2}\right)$, which were just over twice the mean size of spur leaves $\left[22 \mathrm{~cm}^{2}\right.$ for NFS and $21 \mathrm{~cm}^{2}$ for FS leaves (data not shown)]. The ES proportion of the total branch LA increased from $8 \%$ at 25 DAFB to $21 \%$ at 75 DAFB. The LA:F of ES almost doubled from 25 to 75 DAFB (Table 1).

Fruit set occurred between 5 and 12 DAFB [256-312 GDD $(\mathrm{FB}=30 \mathrm{Apr})$.$] , and fruit growth at SI continued until 32$ DAFB (319-483 GDD). Stage II occurred from 33 to 46 DAFB (492604 GDD), with the greatest increase in fruit FW between 44 and 56 DAFB, continuing through 75 DAFB (Table 1). Between 44 and 56 DAFB, fruit FW gain averaged $0.2 \mathrm{~g} \cdot \mathrm{d}^{-1}$, and between 56 and $75 \mathrm{DAFB}$, fruit $\mathrm{FW}$ gain averaged $0.13 \mathrm{~g} \cdot \mathrm{d}^{-1}$. The end of SIII coincided with terminal budset at 75 DAFB (618-1135 GDD). The number of fruit per branch varied from 95 to 66 , decreasing over time because of natural fruit drop. This resulted in a maximum LA:F ratio of $60.4 \mathrm{~cm}^{2}$ at the end of SIII. This low LA:F value explains the relatively low fruit FW attained at maturity for these branches. Whiting and Lang (2004) reported that a LA:F ratio of around $210 \mathrm{~cm}^{2}$ is required to produce sweet cherry fruit weights of 9-10 g, depending on the growing location. Therefore, the branches in this experiment were source-limited for the competition between fruit and shoot growth (Grossman and DeJong, 1995; Pavel and DeJong, 1993).

During the 25-75 DAFB sampling period, the total branch DW increased $178 \%$ as shown in Fig. 1. Most of this increase was attributed to fruit DW, which increased 534\% over the sampling period. The proportional DW increases in the other organs-tissues was 448\% for ES leaves and shoot growth, 69\% for NFS leaves and wood, and 49\% for FS leaves and wood. More than $50 \%$ of the total DW for the individual branch was attributed to fruit at harvest. These data imply proportional sink activities that were highest for fruit, followed by new shoots.

\section{${ }^{13} \mathrm{C}$ Translocation patterns in 2-year-old branches}

TOTAL ${ }^{13} \mathrm{C}$ IN LEAVES AND FRUIT IMMEDIATELY AFTER PULSING. All experimental branches labeled were highly enriched by each ${ }^{13} \mathrm{CO}_{2}$ pulse, as indicated by total ${ }^{13} \mathrm{C}$ content immediately after pulsing (Table 2). Total ${ }^{13} \mathrm{C}$ content was highest at 75 DAFB, when fruit were fully ripe and ES growth was essentially complete. The greatest enrichment generally occurred from labeling the FS branch section, especially during SI and the most rapid phase of fruit growth during mid-SIII. All three-branch sections were comparably enriched at 40, 44, and 75 DAFB. Twenty-five ES were shorter and with fewer leaves resulting in lower enrichment levels than spur leaves.

Fruit on the FS branch section were directly exposed to ${ }^{13}$ $\mathrm{CO}_{2}$ and the presence of significant levels of ${ }^{13} \mathrm{C}$ in fruit immediately after pulsing indicated that fruit were actively photosynthesizing (Table 3 ). The ${ }^{13} \mathrm{C}$ content in fruit was highest at 25 DAFB. Fruit fixation was significant but less at 40 and 44 DAFB, and became minimal at 56 and 75 DAFB, corresponding to the later stages of ripening with loss of chlorophyll and increased anthocyanin synthesis. Fruit photosynthesis has been reported for sour cherry [P. cerasus (Kappes and Flore, 1986, 1989)]. It is likely that ${ }^{13} \mathrm{C}$ fixed directly by fruit mainly affect the $\mathrm{C}$ budget of individual fruit (DeJong and Walton, 1989; Hansen, 1970; Kappes, 1985). In sour cherry, fruit gross photosynthesis contributed $19 \%, 30 \%$, and $1.5 \%$ of the carbohydrates $\left(\mathrm{CH}_{2} \mathrm{O}\right)$ used during SI, SII, and SIII, respectively. Seventy percent of the $\mathrm{CH}_{2} \mathrm{O}$ is incorporated into fruit DW, whereas the rest is used in dark respiration (Flore and Layne, 1999). In apple, fruit photosynthesis constituted $<15 \%$ of the total C supply during the season (Jones, 1981), although it may contribute to early fruit growth (Lakso et al., 1999).

Total ${ }^{13} \mathrm{C}$ in leaves AND FRUIT 48 h AFTER PUlSing. Across all labeling dates, the total amount of ${ }^{13} \mathrm{C}$ recovered in the branches $48 \mathrm{~h}$ after pulsing was lower than the amount of ${ }^{13} \mathrm{C}$ fixed initially (Table 2 vs. Tables 4-6), indicating likely export of ${ }^{13} \mathrm{C}$ to other parts of the tree and respiratory loss. Loescher et al. (1986) estimated that $16 \%$ to $23 \%$ of the total $\mathrm{CH}_{2} \mathrm{O}$ requirements for sweet cherry fruit growth are used in respiration, whereas in peach $16 \%$ to $20 \%$ of the seasonal $\mathrm{CH}_{2} \mathrm{O}$ requirements are respired by developing fruit (DeJong and Walton, 1989). A large proportion of the ${ }^{13} \mathrm{C}$ remained in the pulsed leaves (Tables 4-6). The exception to this was at 56

Table 1. 'Ulster'/‘Gisela ${ }^{\circledR} 6$ ' sweet cherry fruit fresh weight $(\mathrm{FW})$ and growth data for 2 -year-old branches $(n=10)$ at each ${ }^{13} \mathrm{CO}_{2}$ pulse-labeling date $[25,40,44,56$, and $75 \mathrm{~d}$ after full bloom (DAFB)]. Full bloom was on $30 \mathrm{Apr}$.

\begin{tabular}{|c|c|c|c|c|c|c|}
\hline \multirow[b]{2}{*}{ DAFB } & \multicolumn{5}{|c|}{ ES leaves (no.) } & \multirow{2}{*}{$\frac{\mathrm{LA}\left(\mathrm{cm}^{2} / \text { fruit }\right)}{(\text { mean })}$} \\
\hline & Fruit FW (g/fruit) & ES length $(\mathrm{cm})$ & $($ mean $\pm \mathrm{SE})$ & LA $\left(\mathrm{cm}^{2} /\right.$ branch $)$ & Fruit (no./branch) & \\
\hline 25 & $1.2 \pm 0.0$ & $9.4 \pm 0.2$ & $10.1 \pm 0.1$ & $2,984 \pm 67$ & $94.5 \pm 3.3$ & 31.6 \\
\hline 40 & $1.5 \pm 0.1$ & $17.9 \pm 0.3$ & $13.3 \pm 0.1$ & $3,292 \pm 83$ & $79.8 \pm 3.4$ & 41.2 \\
\hline 56 & $4.1 \pm 0.2$ & $28.2 \pm 0.5$ & $17.6 \pm 0.2$ & $3,900 \pm 80$ & $68.7 \pm 3.0$ & 56.8 \\
\hline 75 & $6.5 \pm 0.3$ & $33.9 \pm 0.9$ & $19.1 \pm 0.1$ & $3,994 \pm 126$ & $66.1 \pm 3.2$ & 60.4 \\
\hline
\end{tabular}

$\mathrm{ES}=$ extension shoot; LA $=$ leaf area. 


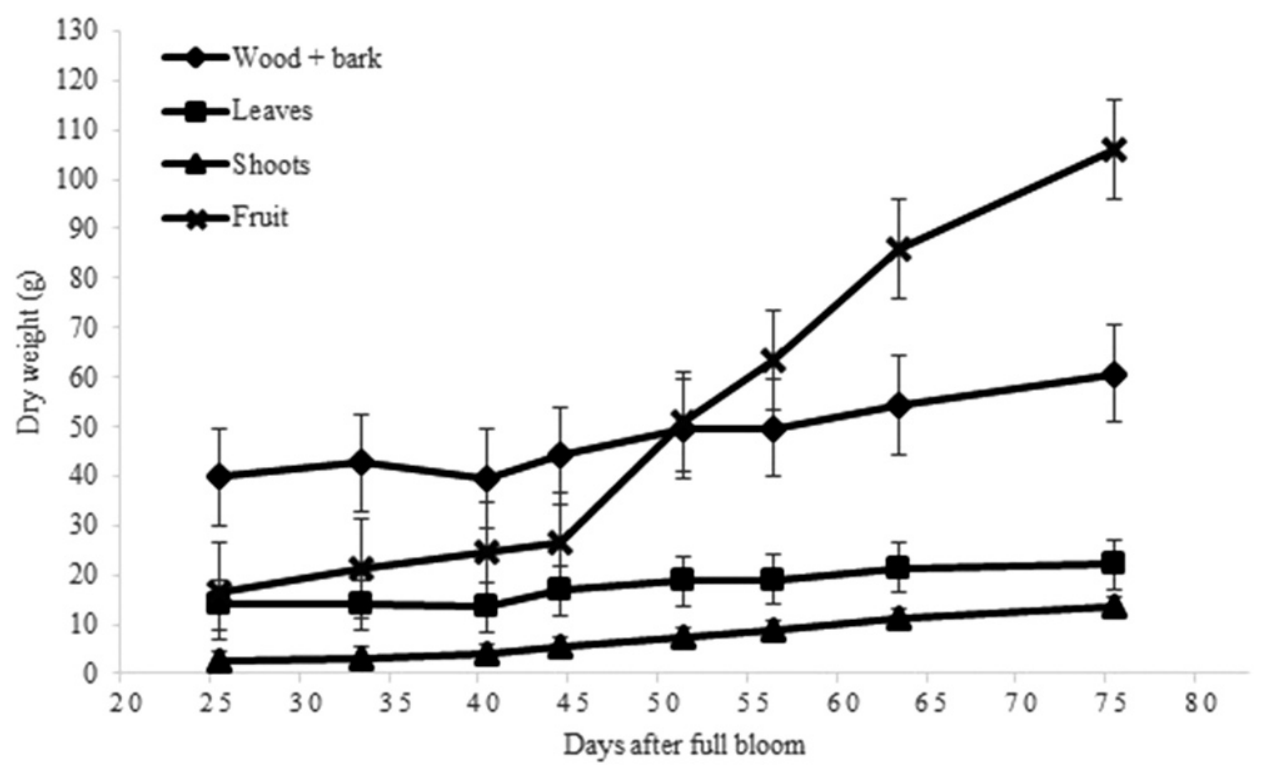

Fig. 1. Total 'Ulster'/'Gisela ${ }^{\circledR} 6$ ' sweet cherry dry weight (DW) accumulation (mean \pm SE) per 2-year-old branch, partitioned into organ types, at each ${ }^{13} \mathrm{CO}_{2}$ pulse-labeling date (see arrows). Full bloom was on $30 \mathrm{Apr}$. $(n=30)$.

Table 2. Total ${ }^{13} \mathrm{C}$ content recovered in 2-year-old branches of 'Ulster'/ 'Gisela ${ }^{\circledR} 6$ ' sweet cherry immediately (after chamber removal) following ${ }^{13} \mathrm{C}$ pulse-labeling to fruiting spur (FS), nonfruiting spur (NFS), and extension shoot (ES) branch sections $(n=10)$ at $25,40,44,56$, and $75 \mathrm{~d}$ after full bloom (DAFB). Calculations were made based on total dry weight (DW) of branches. Full bloom was on 30 Apr.

\begin{tabular}{|c|c|c|c|c|c|}
\hline \multirow{3}{*}{$\begin{array}{l}{ }^{13} \mathrm{C} \text {-pulsed leaf } \\
\text { population }\end{array}$} & \multicolumn{5}{|c|}{${ }^{13} \mathrm{C}$-pulse date (DAFB) } \\
\hline & 25 & 40 & 44 & 56 & 75 \\
\hline & \multicolumn{5}{|c|}{ Total ${ }^{13} \mathrm{C}$ content (mg/branch) } \\
\hline FS leaves & $42.9 \mathrm{a}^{\mathrm{z}}$ & $34.9 a$ & $36.8 \mathrm{a}$ & $47.1 \mathrm{a}$ & $46.0 \mathrm{a}$ \\
\hline NFS leaves & $34.5 \mathrm{ab}$ & $31.8 a$ & $38.1 \mathrm{a}$ & $38.9 \mathrm{a}$ & $42.7 \mathrm{a}$ \\
\hline ES leaves & $28.5 \mathrm{~b}$ & $32.7 a$ & $35.2 \mathrm{a}$ & $30.8 \mathrm{a}$ & $44.7 \mathrm{a}$ \\
\hline
\end{tabular}

${ }^{\mathrm{z}}$ Means within a column followed by the same small letter are not significantly at different $\alpha=0.05$. Mean separation using Tukey's test at $P=0.05$.

DAFB, when the ${ }^{13} \mathrm{C}$ remaining in all of the pulsed leaf populations was at the lowest relative levels compared with all other pulse dates. High sink activity related to rapid fruit growth and reduced leaf $\mathrm{CH}_{2} \mathrm{O}$ levels has been reported previously in sweet cherry (Roper et al., 1987, 1988) and japanese pear [Pyrus pyrifolia (Teng et al., 2001)].

At $48 \mathrm{~h}$ after pulsing, there were significant differences in ${ }^{13} \mathrm{C}$ content among different organs of the branch, depending on the pulsed leaf population (Tables 4-6). For the three source leaf populations, the greatest proportion of translocated ${ }^{13} \mathrm{C}$ was detected in fruit throughout SI, SII, and SIII. However, there were significant differences among leaf populations regarding the relative amount of ${ }^{13} \mathrm{C}$ accumulated in fruit for each pulse-labeling date. The highest relative ${ }^{13} \mathrm{C}$ levels in fruit were detected when FS leaves were the labeled source; these ranged from $57 \%$ to $63 \%$ across all labeling dates except at 56 DAFB when levels peaked at $79 \%$ (Table 4). The second most important $\mathrm{C}$ source for fruit was NFS leaves, with relative ${ }^{13} \mathrm{C}$ levels ranging from around $32 \%$ at 40,44 , and 75 DAFB to $71 \%$ at 56 DAFB (Table 5). The lowest relative ${ }^{13} \mathrm{C}$ levels recovered in fruit, around $22 \%$ to $28 \%$, were from ES leaves as the source of photoassimilates, although again at $56 \mathrm{DAFB}$, relative ${ }^{13} \mathrm{C}$ levels peaked at 59\% (Table 6). These consistently high relative ${ }^{13} \mathrm{C}$ levels recovered in fruit from all source leaf populations during mid-SIII suggest that this is the period of strongest fruit sink strength and the period when additional source LA is most needed to optimize fruit growth.

Fruiting spur, NFS, and ES leaves all supplied current photoassimilates to fruit and vegetative growth during SI, SII, and SIII of fruit development. Across all pulselabeling dates, ${ }^{13} \mathrm{C}$ fixed by $\mathrm{FS}$ leaves was translocated predominantly to fruit and wood subtending those leaves (Table 4). In $87 \%$ of ${ }^{13} \mathrm{C}$-enriched branches, very minor acropetal translocation of ${ }^{13} \mathrm{C}$ was detected in NFS leaves, NFS wood, ES leaves, and wood. ${ }^{13} \mathrm{C}$ fixed by NFS leaves was translocated predominantly basipetally to fruit and fruiting wood (Table 5). Significant amounts of ${ }^{13} \mathrm{C}$ were detected in the wood subtending the NFS leaves. However, acropetal ${ }^{13} \mathrm{C}$ translocation to ES wood and leaves also was observed. Only $12 \%$ of enriched branches did not exhibit translocation to either FS or ES. Bidirectional translocation from the NFS leaves has been shown previously for sweet cherry on the dwarfing rootstock Gi5, in which NFS leaves translocated ${ }^{13} \mathrm{C}$ primarily to fruit during final swell, but also to ES growth (Ayala, 2004). Unidirectional and bidirectional transport from different leaf populations also have been reported for apple (Corelli Grappadelli et al., 1994; Hansen, 1969; Toselli et al., 2014; Wang et al., 2003; Zhou et al., 2015), sour cherry (Kappes and Flore, 1986; Toldam-Andersen, 1998), japanese pear (Zhang et al., 2005), pecan [Carya illinoinensis (Davis and Sparks, 1974)], persimmon [Diospyrus khaki (Nakano et al., 1998; Simkhada et al., 2007)], and grape [Vitis vinifera (Hale and Weaver, 1962)]. The highest total recoveries of ${ }^{13} \mathrm{C}$ for both spur leaf populations occurred 56 DAFB, coincident with peak fruit growth as shown in Fig. 1.

ES growth was not a strong sink for assimilates during sweet cherry fruit development in these relatively heavily-cropped 'Ulster' trees on the semivigorous rootstock Gi6. Minimal amounts of ${ }^{13} \mathrm{C}(<1 \%)$ were found in ES when FS and NFS leaves were labeled (Tables 4 and 5). Conversely, Kappel (1991) reported that, with 'Lambert' sweet cherry on vigorous $P$. avium seedling rootstocks, ES growth had a greater sink strength for photosynthates than fruit. Source-sink relationships and relative $\mathrm{C}$ distribution can be influenced by rootstock genotype (Caruso et al., 1997; Moing and Gaudillere, 1992). Fruit growth can affect ES development negatively in sweet cherry trees on dwarfing rootstocks (Whiting, 2005; Whiting and Lang, 2004). In 'Bing' on semidwarfing Gi5, heavy cropping reduced ES elongation and DW accumulation (Correa, 2008). Similarly in peach, the presence of fruit influenced primary and secondary growth (Costes et al., 2000), and stem length and DW accumulation, suggesting competition for $\mathrm{C}$ between vegetative growth and fruit (Grossman and DeJong, 
Table 3. Total ${ }^{13} \mathrm{C}$ content recovered in 'Ulster'/ 'Gisela ${ }^{\circledR} 6$ ' sweet cherry fruit sampled from 2-year-old branches $(n=10)$ immediately (after chamber removal) following ${ }^{13} \mathrm{C}$ pulselabeling of the fruiting spur (FS) section at 25, 40, 44, 56, and $75 \mathrm{~d}$ after full bloom (DAFB). Full bloom was on $30 \mathrm{Apr}$.

\begin{tabular}{lcccc}
\hline \multicolumn{5}{c}{${ }^{13} \mathrm{C}$-pulse date (DAFB) } \\
\hline 25 & 40 & 44 & 56 & 75 \\
\hline \multicolumn{5}{c}{ Fruit ${ }^{13} \mathrm{C}$ content $\left(\mu \mathrm{g} \cdot \mathrm{g}^{-1} \mathrm{DW}\right)$} \\
\hline $188.3 \mathrm{a}^{\mathrm{z}}$ & $69.3 \mathrm{~b}$ & $98.0 \mathrm{~b}$ & $8.4 \mathrm{c}$ & $11.6 \mathrm{c}$
\end{tabular}

${ }^{\mathrm{z}}$ Means within a row followed by the same small letter are not significantly at different $\alpha=0.05$. Mean separation using Tukey's test at $P=0.05$.

$\mathrm{DW}=$ dry weight.

Table 4. Total ${ }^{13} \mathrm{C}$ recovered per branch and relative ${ }^{13} \mathrm{C}$ distribution among organs on 2-year-old branches of 'Ulster'/'Gisela ${ }^{\circledR} 6$ ' sweet cherry trees $48 \mathrm{~h}$ after ${ }^{13} \mathrm{CO}_{2}$ pulsing of the fruiting spur (FS) branch section $(n=10)$. Percentages are based on absolute amounts of ${ }^{13} \mathrm{C}$ recovered for each organ at each ${ }^{13} \mathrm{CO}_{2}$ pulse-labeling date $[25,40,44$, 56, and $75 \mathrm{~d}$ after full bloom (DAFB)]. Full bloom was on $30 \mathrm{Apr}$.

\begin{tabular}{|c|c|c|c|c|c|}
\hline \multirow[b]{3}{*}{ Total ${ }^{13} \mathrm{C}$ recovered $(\mu \mathrm{g})$} & \multicolumn{5}{|c|}{${ }^{13} \mathrm{C}$-pulse date (DAFB) } \\
\hline & 25 & 40 & 44 & 56 & 75 \\
\hline & $\overline{22,874}$ & $\overline{18,793}$ & $\overline{23,456}$ & 36,259 & 26,652 \\
\hline Organ sampled & \multicolumn{5}{|c|}{ Relative ${ }^{13} \mathrm{C}$ distribution (\%) } \\
\hline Fruit & $63.2^{z}$ & $59.9^{\mathrm{z}}$ & $58.9^{\mathrm{z}}$ & $79.1^{\mathrm{z}}$ & $57.3^{z}$ \\
\hline FS leaves & $32.5^{z}$ & $30.5^{z}$ & $34.1^{z}$ & $17.9^{z}$ & $36.4^{z}$ \\
\hline NFS leaves & $0.7 \mathrm{a}^{\mathrm{y}}$ & $0.2 \mathrm{c}$ & $0.0 \mathrm{~b}$ & $0.3 \mathrm{a}$ & $0.2 \mathrm{a}$ \\
\hline ES leaves & $0.1 \mathrm{a}$ & $0.0 \mathrm{c}$ & $0.0 \mathrm{~b}$ & $0.0 \mathrm{a}$ & $0.2 \mathrm{a}$ \\
\hline FS wood & $3.0 \mathrm{a}$ & $8.8 \mathrm{a}$ & $7.0 \mathrm{a}$ & $2.6 \mathrm{a}$ & $5.4 \mathrm{a}$ \\
\hline NFS wood & $0.5 \mathrm{a}$ & $0.6 \mathrm{~b}$ & $0.0 \mathrm{~b}$ & $0.1 \mathrm{a}$ & $0.4 \mathrm{a}$ \\
\hline ES wood & $0.0 \mathrm{a}$ & $0.0 \mathrm{c}$ & $0.0 \mathrm{~b}$ & $0.0 \mathrm{a}$ & $0.1 \mathrm{a}$ \\
\hline
\end{tabular}

${ }^{\mathrm{z}}$ Organs labeled with ${ }^{13} \mathrm{C}$ directly were not considered in the statistical analysis.

${ }^{\mathrm{y}}$ Percentages within a column followed by the same letter are not significantly at different $\alpha=0.05$. Mean separation using Tukey's test at $P=0.05$.

$\mathrm{NFS}=$ nonfruiting spurs; $\mathrm{ES}=$ extension shoots.

1995). This competition requires orchard management strategies to adjust the LA:F ratio to avoid an imbalance between vegetative and reproductive sinks during fruit development (Ayala and Andrade, 2009; Lang, 2001a, 2001b; Whiting and Lang, 2004).

In this experiment, when terminal ES leaves were labeled directly, the basal and medial leaves had higher ${ }^{13} \mathrm{C}$ enrichments than did young apical leaves (data not shown). Young ES apical leaves imported minimal amounts of ${ }^{13} \mathrm{C}$ fixed by FS and NFS leaves. In sour cherry, ES become net $\mathrm{CH}_{2} \mathrm{O}$ exporters $17 \mathrm{~d}$ after budbreak (Kappes, 1985). ES of apple begin C export with 9-17 leaves (Corelli-Grappadelli et al., 1994; Lakso and Corelli-Grappadelli, 1992), whereas peach ES begin exporting to fruit 30 DAFB (Corelli-Grappadelli et al., 1996).

${ }^{13} \mathrm{C}$ fixed by the ES leaf population was translocated basipetally to NFS leaves, NFS wood, FS leaves, FS wood, and fruit (Table 6). Several branches (16\%) did not translocate ${ }^{13} \mathrm{C}$ to either FS or NFS leaves. Most of the translocated ${ }^{13} \mathrm{C}$ was in fruit, followed by either NFS wood or FS wood. The highest ${ }^{13} \mathrm{C}$ contents in fruit were found at $56 \mathrm{DAFB}$, when ES were $30 \mathrm{~cm}$ (20 leaves) in length (Table 1), and the highest total recovery of ${ }^{13} \mathrm{C}$ occurred at 75 DAFB, when shoots were $34 \mathrm{~cm}$
Table 5. Total ${ }^{13} \mathrm{C}$ recovered and relative ${ }^{13} \mathrm{C}$ distribution among organs on 2-year-old branches $(n=10)$ of 'Ulster'/ 'Gisela ${ }^{\circledR} 6$ ' sweet cherry trees $48 \mathrm{~h}$ after ${ }^{13} \mathrm{CO}_{2}$ pulsing of the nonfruiting spur (NFS) branch section. Percentages are based on absolute amounts of ${ }^{13} \mathrm{C}$ recovered for each organ at each pulse-labeling date $[25,40,44,56$, and $75 \mathrm{~d}$ after full bloom (DAFB)]. Full bloom was on $30 \mathrm{Apr}$.

\begin{tabular}{|c|c|c|c|c|c|}
\hline \multirow[b]{3}{*}{ Total ${ }^{13} \mathrm{C}$ recovered $(\mu \mathrm{g})$} & \multicolumn{5}{|c|}{${ }^{13} \mathrm{C}$-pulse date (DAFB) } \\
\hline & 25 & 40 & 44 & 56 & 75 \\
\hline & $\overline{24,098}$ & $\overline{19,732}$ & $\overline{23,375}$ & $\overline{34,527}$ & $\overline{26,553}$ \\
\hline Organ sampled & \multicolumn{5}{|c|}{ Relative ${ }^{13} \mathrm{C}$ distribution (\%) } \\
\hline Fruit & $45.8 \mathrm{a}^{\mathrm{z}}$ & $31.7 \mathrm{a}$ & $31.3 \mathrm{a}$ & $70.9 \mathrm{a}$ & $32.7 \mathrm{a}$ \\
\hline FS leaves & $0.2 \mathrm{c}$ & $0.7 \mathrm{~d}$ & $0.0 \mathrm{c}$ & $0.5 \mathrm{c}$ & $0.2 \mathrm{c}$ \\
\hline NFS leaves & $41.2^{\mathrm{y}}$ & $42.7^{y}$ & $46.1^{\mathrm{y}}$ & $19.9^{\mathrm{y}}$ & $49.3^{y}$ \\
\hline ES leaves & $0.2 \mathrm{c}$ & $0.1 \mathrm{~d}$ & $0.3 \mathrm{c}$ & $0.2 \mathrm{c}$ & $0.5 \mathrm{c}$ \\
\hline FS wood & $8.4 \mathrm{~b}$ & $16.9 \mathrm{~b}$ & $14.5 \mathrm{~b}$ & $5.1 \mathrm{~b}$ & $12.1 \mathrm{~b}$ \\
\hline NFS wood & $4.2 \mathrm{bc}$ & $7.8 \mathrm{c}$ & $7.6 \mathrm{bc}$ & $3.3 \mathrm{bc}$ & $5.0 \mathrm{bc}$ \\
\hline ES wood & $0.0 \mathrm{c}$ & $0.1 \mathrm{~d}$ & $0.2 \mathrm{c}$ & $0.1 \mathrm{c}$ & $0.2 \mathrm{c}$ \\
\hline
\end{tabular}

${ }^{\mathrm{z}}$ Percentages within a column followed by the same letter are not significantly at different $\alpha=0.05$. Mean separation using Tukey's test at $P=0.05$.

${ }^{\mathrm{y}}$ Organs labeled with ${ }^{13} \mathrm{C}$ directly were not considered in the statistical analysis.

$\mathrm{FS}=$ fruiting spurs; $\mathrm{ES}=$ extension shoots.

Table 6. Total ${ }^{13} \mathrm{C}$ recovered and relative ${ }^{13} \mathrm{C}$ distribution among organs on 2-year-old branches $(n=10)$ of 'Ulster'/'Gisela ${ }^{\circledR} 6$ ' sweet cherry trees $48 \mathrm{~h}$ after ${ }^{13} \mathrm{CO}_{2}$ pulsing of the extension shoot branch section. Percentages are based on absolute amounts of ${ }^{13} \mathrm{C}$ recovered for each organ at each pulse-labeling date $[25,40,44$, 56 , and $75 \mathrm{~d}$ after full bloom (DAFB)]. Full bloom was on $30 \mathrm{Apr}$.

\begin{tabular}{|c|c|c|c|c|c|}
\hline \multirow[b]{3}{*}{ Total ${ }^{13} \mathrm{C}$ recovered $(\mu \mathrm{g})$} & \multicolumn{5}{|c|}{${ }^{13} \mathrm{C}$-pulse date (DAFB) } \\
\hline & 25 & 40 & 44 & 56 & 75 \\
\hline & 9,393 & $\overline{18,294}$ & $\overline{21,486}$ & $\overline{19,117}$ & $\overline{27,26}$ \\
\hline Organ sampled & \multicolumn{5}{|c|}{ Relative ${ }^{13} \mathrm{C}$ distribution (\%) } \\
\hline Fruit & $27.2 \mathrm{a}^{\mathrm{z}}$ & $22.3 \mathrm{a}$ & $17.5 \mathrm{a}$ & $59.2 \mathrm{a}$ & 28.3 \\
\hline FS leaves & $0.2 \mathrm{c}$ & $0.0 \mathrm{c}$ & $0.1 \mathrm{~d}$ & $0.5 \mathrm{~b}$ & 0.0 \\
\hline NFS leav & $0.4 \mathrm{c}$ & $0.1 \mathrm{c}$ & $0.0 \mathrm{~d}$ & $0.4 \mathrm{c}$ & 0.2 \\
\hline ES leaves & $50.4^{y}$ & $46.3^{y}$ & $59.8^{\mathrm{y}}$ & $28.1^{\mathrm{y}}$ & $45.0^{y}$ \\
\hline FS wood & $8.8 \mathrm{~b}$ & $10.1 \mathrm{~b}$ & $4.8 \mathrm{c}$ & $5.0 \mathrm{~b}$ & 10.7 \\
\hline NFS wood & $8.1 \mathrm{~b}$ & $15.7 \mathrm{ab}$ & $9.1 \mathrm{~b}$ & $3.7 \mathrm{~b}$ & 10.0 \\
\hline ES wood & $4.9 \mathrm{bc}$ & $5.5 \mathrm{~b}$ & $8.7 \mathrm{~b}$ & $3.1 \mathrm{~b}$ & 5.8 \\
\hline
\end{tabular}

${ }^{\mathrm{z}}$ Percentages within a column followed by the same letter are not significantly at different $\alpha=0.05$. Mean separation using Tukey's test at $P=0.05$.

${ }^{\mathrm{y}}$ Organs labeled with ${ }^{13} \mathrm{C}$ directly were not considered in the statistical analysis.

$\mathrm{FS}=$ fruiting spurs; NFS = nonfruiting spurs; ES = extension shoots.

(i.e., 22 leaves) in length. The lowest total recovery of ${ }^{13} \mathrm{C}$ was at $25 \mathrm{DAFB}$, when ES were $10 \mathrm{~cm}$ in length and had only 10 leaves. The lowest ${ }^{13} \mathrm{C}$ export from ES was at the beginning of SIII (44 DAFB, 570 GDD), when shoots were elongating rapidly.

\section{Translocation of ${ }^{13} \mathrm{C}$ to, and within, fruit}

When the total ${ }^{13} \mathrm{C}$ translocation to the fruit, from all sources, is combined for each pulsing date, the extremely strong fruit sink activity at 56 DAFB is apparent with more than twice the total ${ }^{13} \mathrm{C}$ content $(65,055 \mu \mathrm{g} /$ fruit $)$ than for that found at any other date (Table 7). On a relative ${ }^{13} \mathrm{C}$ distribution basis, the FS leaf population always contributed the most, around half of that 
Table 7. Total ${ }^{13} \mathrm{C}$ content in sweet cherry fruit derived from all pulsed sources on 2-year-old branches $(n=10)$ of 'Ulster'/'Gisela ${ }^{\circledR} 6$ ' trees $48 \mathrm{~h}$ after ${ }^{13} \mathrm{CO}_{2}$ pulsing of fruiting spur (FS) leaves and fruit, nonfruiting spur (NFS) leaves, and extension shoot (ES) leaves. Percentages are based on absolute amounts of ${ }^{13} \mathrm{C}$ recovered in fruit at each pulse-labeling date $[25,40,44,56$, and $75 \mathrm{~d}$ after full bloom (DAFB)]. Full bloom was on 30 Apr.

\begin{tabular}{|c|c|c|c|c|}
\hline \multirow[b]{2}{*}{ DAFB } & \multicolumn{3}{|c|}{ Relative ${ }^{13} \mathrm{C}$ contribution from each pulsed source (\%) } & \multirow{2}{*}{$\begin{array}{c}\text { Total }{ }^{13} \mathrm{C} \text { content } \\
\text { in fruit }(\mu \mathrm{g})\end{array}$} \\
\hline & FS leaves & NFS leaves & ES leaves & \\
\hline 25 & $49.4 \mathrm{a}^{\mathrm{z}}$ & $40.9 \mathrm{~b}$ & $9.8 \mathrm{c}$ & $26,851.7$ \\
\hline 40 & $50.5 \mathrm{a}$ & $30.4 \mathrm{~b}$ & $19.1 \mathrm{c}$ & $20,648.2$ \\
\hline 44 & $53.9 \mathrm{a}$ & $31.1 \mathrm{~b}$ & $15.0 \mathrm{c}$ & $23,223.4$ \\
\hline 56 & $43.9 \mathrm{a}$ & $37.6 \mathrm{a}$ & $18.5 \mathrm{c}$ & $65,055.0$ \\
\hline 75 & $46.5 \mathrm{a}$ & $28.4 \mathrm{~b}$ & $25.1 \mathrm{~b}$ & $31,550.6$ \\
\hline
\end{tabular}

${ }^{\mathrm{z}}$ Means within a row followed by the same small case are not significantly different $\alpha=0.05$. Mean separation using Tukey's test at $P=0.05$.

Table 8. Relative ${ }^{13} \mathrm{C}$ partitioning between 'Ulster'/‘Gisela ${ }^{\circledR} 6$ ' sweet cherry fruit pericarp and endocarp $(n=5) 48 \mathrm{~h}$ after ${ }^{13} \mathrm{CO}_{2}$ pulsing of fruiting spur (FS) leaves and fruit at $25,40,44,56$, and $75 \mathrm{~d}$ after full bloom (DAFB). Calculations and statistical analyses are based on absolute amounts of ${ }^{13} \mathrm{C}$ recovered at each pulse-labeling date. Full bloom was on 30 Apr.

\begin{tabular}{lccccc}
\hline & \multicolumn{5}{c}{ Relative ${ }^{13} \mathrm{C}$ distribution (\%) } \\
\cline { 2 - 6 } Tissue & 25 & 40 & 44 & 56 & 75 \\
\cline { 2 - 6 } Pericarp & $25.8 \mathrm{a}^{\mathrm{z}}$ & $21.4 \mathrm{a}$ & $32.3 \mathrm{a}$ & $77.4 \mathrm{~b}$ & $83.4 \mathrm{~b}$ \\
Endocarp & $74.2 \mathrm{a}$ & $78.6 \mathrm{a}$ & $67.7 \mathrm{ab}$ & $22.6 \mathrm{a}$ & $16.6 \mathrm{a}$
\end{tabular}

${ }^{\mathrm{z}}$ Means within a column followed by the same letter are not significantly at different $\alpha=0.05$. Mean separation using Tukey's test at $P=0.05$.

recovered. At 25 DAFB, the NFS leaves were an important source for ${ }^{13} \mathrm{C}$, and during the period of greatest fruit sink demand, the NFS leaves were statistically similar to the FS leaves. As the ES leaf population reached its maximum LA (75 DAFB), the ${ }^{13} \mathrm{C}$ provided by those leaves became statistically similar to that of the NFS leaf population, with each providing $\approx 25 \%$ of the ${ }^{13} \mathrm{C}$ found in the mature fruit.

In this study, the sink demand of sweet cherry fruit varied during development and fruit were stronger sinks for photoassimilates than shoots, as has been reported for peach (Grossman and DeJong, 1995). In sour cherry the highest fruit sink strength was during SIII (Flore and Layne, 1999). During SI, sink activity of a small sweet cherry fruit requires ${ }^{13} \mathrm{C}$ assimilates for cell division. At this stage in our study, the highest ${ }^{13} \mathrm{C}$ atom percent excess per unit basis was detected in fruit. Hansen (1987) indicated that increased sink activity of fruit promotes the uptake of assimilates, which in turn accelerates its growth rate. Sour cherry small fruit exhibit strong sink activity by removing $\mathrm{C}$ from the translocation system, which supports their high specific growth rate during early fruit development (Toldam-Andersen, 1998). Similarly, the sink activity of immature small grape berries is important for DW accumulation during the first week of growth when cell expansion is slow (Coombe, 1989).

The distribution of translocated ${ }^{13} \mathrm{C}$ between the fruit pericarp (epicarp + mesocarp) and pit (endocarp + embryo) changed significantly during development (Table 8 ). From late SI through most of SII (25-40 DAFB), 74\% to $79 \%$ of the total ${ }^{13} \mathrm{C}$ in the fruit was recovered from the pit. The transition from SII to SIII (44 DAFB) marked the beginning of a shift in relative ${ }^{13} \mathrm{C}$ distribution, from 2:1 pit:pericarp at 44 DAFB to $1: 3$ at 56
DAFB and 1:4 at 75 DAFB. Teng et al. (2001) reported that japanese pear fruit accumulated most of the ${ }^{13} \mathrm{C}$ in the flesh during the period of active growth. Similar results have been reported for peach (CorelliGrappadelli et al., 1996).

\section{Conclusions}

This study examined how sourcesink relationships at specific phenological stages influence the uptake and distribution of current season photosynthates in sweet cherry trees on highly productive rootstocks such as Gi6. On average, during fruit development, FS leaves contributed more ${ }^{13} \mathrm{C}(60 \%$ to $80 \%)$ to fruit than did NFS (30\% to $70 \%$ ) and ES (18\% to $60 \%$ ) leaves. The exception was at 56 DAFB (mid-SIII, $812 \mathrm{GDD}$ ), a period of rapid cell enlargement and DW accumulation, when the amounts of ${ }^{13} \mathrm{C}$ translocated to fruit were significantly higher from all ${ }^{13} \mathrm{C}$ sources compared with the other pulse-labeling dates. In 'Ulster'/Gi6 trees, SI (319-483 GDD) and mid-SIII (753-874 GDD) were the critical periods of potentially restricted $\mathrm{C}$ availability, because of limited ES LA during the former period and high fruit sink strength during the latter period.

Therefore, these results confirm the need to potentially reduce crop load during the early stages of fruit development to avoid negatively affecting fruit quality, particularly, size, SSC, firmness, and postharvest life. This has important implications for orchard management strategies such as dormant pruning, fruit thinning (i.e., intensity and type), and tree nutrition to maintain adequate LA to support fruit growth. To reduce the potential for resource limitations during fruit development, particularly in highly precocious dwarfing rootstock/scion combinations, more intensive dormant pruning could be imposed, with complementary flower or fruit thinning in orchards prone to excessively high yields. Heading cuts may be favored over thinning cuts to stimulate new ES LA and reduce the density of future spur flower bud formation. Fertilization strategies to build storage reserves for the promotion of larger FS and NFS leaf development in spring would also shift the LA:F ratio favorably. Additional studies of sweet cherry source-sink relationships at specific phenological stages would be valuable to further examine partitioning variations in relation to growing conditions and other rootstocks and varieties.

\section{Literature Cited}

Ayala, M. 2004. Carbon partitioning in sweet cherry (Prunus avium L.) on dwarfing precocious rootstocks during fruit development. Michigan State Univ., East Lansing, MI, PhD Diss.

Ayala, M. and P. Andrade. 2009. Effects of fruiting spur thinning on fruit quality and vegetative growth of sweet cherry (Prunus avium). Revista Ciencia e Investigación Agraria 36:443-450.

Ayala, M. and G.A. Lang. 2004. Examining the influence of different leaf populations in sweet cherry fruit quality. Acta Hort. 636:481488.

Ayala, M. and G.A. Lang. 2008. ${ }^{13}$ C-Photoassimilate partitioning in sweet cherry on dwarfing rootstocks during fruit development. Acta Hort. 795:625-632. 
Ayala, M. and G.A. Lang. 2015. ${ }^{13}$ C-Photoassimilate partitioning in sweet cherry (Prunus avium L.) during early spring. Ciencia e Investigación Agraria 42:191-203.

Basile, B., M.J. Mariscal, K.R. Day, J.S. Johnson, and T.M. DeJong. 2002. Japanese plum (Prunus salicina L.) fruit growth: Seasonal pattern of source/sink limitations. J. Amer. Pomol. Soc. 56:86-93.

Berman, M.E. and T.M. DeJong. 1996. Water stress and crop load effects on fruit flesh weights in peach (Prunus persica L.). Tree Physiol. 16:859-864.

Boutton, T.W. 1991. Stable carbon isotope ratios of natural materials: I. Sample preparation and mass spectrometric analysis, p. 155-200. In: D.C. Coleman and B. Fry (eds.). Carbon isotope techniques. Academic Press, New York, NY.

Caruso, T.P., P. Inglese, M. Sidari, and F. Sottile. 1997. Rootstock influences seasonal dry matter and carbohydrate content and partitioning in above ground components of 'Flordaprince' peach trees. J. Amer. Soc. Hort. Sci. 122:673-679.

Coombe, B.G. 1989. The grape as a sink. Acta Hort. 239:149-159.

Corelli-Grappadelli, L., A.N. Lakso, and J.A. Flore. 1994. Early season patterns of carbohydrate partitioning in exposed and shaded apple branches. J. Amer. Soc. Hort. Sci. 119:596-603.

Corelli-Grappadelli, L., G. Ravaglia, and A. Asirelli. 1996. Shoot type and light exposure influence carbon partitioning in peach cv. Elegant Lady. J. Hort. Sci. 71:533-543.

Correa, J.E. 2008. Effect of spur thinning on the photoassimilate translocation and the morphological characteristics of sweet cherry fruit (Prunus avium L.) in the combination 'Bing'/'Gisela ${ }^{\circledR} 5$ '. Pontificia Universidad Católica de Chile, Santiago, Chile, MSc Thesis.

Costes, E., D. Fournier, and J.C. Salles. 2000. Changes in primary and secondary growth as influenced by crop load in 'Fantasme' apricot tree. J. Hort. Sci. Biotechnol. 75:510-519.

Davis, J.T. and D. Sparks. 1974. Assimilation and translocation patterns of carbon-14 in the shoots of fruiting pecan trees. J. Amer. Soc. Hort. Sci. 99:468-480.

DeJong, T.M. 1999. Developmental and environmental control of drymatter partitioning in peach. HortScience 34:1037-1040.

DeJong, T.M. and E.F. Walton. 1989. Carbohydrate requirements of peach fruit growth and respiration. Tree Physiol. 5:329-335.

Farrar, J.F. 1996. Sinks-integral parts of a whole plant. J. Expt. Bot. 47:1273-1279.

Fischer, G., P.J. Almanza-Merchán, and F. Ramírez. 2012. Source-sink relationships in fruit species: A review. Revista Colombiana de Ciencias Horticolas 6:238-253.

Flore, J.A. 1994. Stone fruit, p. 233-270. In: B. Schaffer and P.C. Andersen (eds.). Handbook of environmental physiology of fruit crops, Volume I: Temperate crops. CRC Press, Boca Raton, FL.

Flore, J.A. and D.R. Layne. 1999. Photoassimilate production and distribution in cherry. HortScience 34:1015-1019.

Grossman, Y.L. and T.M. DeJong. 1995. Maximum vegetative growth potential and seasonal partterns of resource dynamics during peach growth. Ann. Bot. 76:473-482.

Hale, C.R. and R.J. Weaver. 1962. The effect of developmental stage on direction of translocation of photosynthates in Vitis vinifera. Hilgardia 33:89-131.

Hansen, P. 1969. ${ }^{14} \mathrm{C}$ studies on apple trees. IV. Photosynthate consumption in fruits in relation to the leaf-fruit ratio and to leaffruit position. Physiol. Plant. 22:186-198.

Hansen, P. 1970. ${ }^{14} \mathrm{C}$ studies on apple trees. VI. The influence of the fruit on the photosynthesis of the leaves, and the relative photosynthetic yields of fruits and leaves. Physiol. Plant. 23:805-810.

Hansen, P. 1987. Source/sink effects in fruits: An evaluation of various elements, p. 29-37. In: C.J. Wright (ed.). Manipulation of fruiting. Butterworths, London, UK.

Jones, H.G. 1981. Carbon dioxide exchange of developing apple (Malus pumila Mill.) fruits. J. Expt. Bot. 32:1203-1210.
Kappel, F. 1991. Partitioning of above-ground dry matter in 'Lambert' sweet cherry trees with or without fruit. J. Amer. Soc. Hort. Sci. 116:201-205.

Kappes, E.M. 1985. Carbohydrate production, balance and translocation in leaves, shoots and fruits of 'Montmorency' sour cherry. Michigan State Univ., East Lansing, MI, PhD Diss.

Kappes, E.M. and J.A. Flore. 1986. Carbohydrate balance models for 'Montmorency' sour cherry leaves, shoots and fruit during development. Acta Hort. 184:123-127.

Kappes, E.M. and J.A. Flore. 1989. Phyllotaxy and stage of leaf and fruit development influence initiation and direction of carbohydrate export from sour cherry leaves. J. Amer. Soc. Hort. Sci. 114:642648

Lakso, A.N. and L. Corelli-Grappadelli. 1992. Implications of pruning and training practices to carbon partitioning and fruit development in apple. Acta Hort. 322:231-239.

Lakso, A.N., J.N. Wünsche, J.W. Palmer, and L. Corelli-Grappadelli. 1999. Measurement and modeling of carbon balance of the apple tree. HortScience 34:1040-1047.

Lang, G.A. 2001a. Critical considerations for sweet cherry training systems. Compact Fruit Tree 34(3):70-73.

Lang, G.A. 2001b. Intensive sweet cherry orchard systems-rootstocks, vigor, precocity, productivity and management. Compact Fruit Tree 34(1):23-26.

Lang, G.A. 2005. Underlying principles of high density sweet cherry production. Acta Hort. 667:325-336.

Li, T., E. Heuvelink, and L.F. Marcelis. 2015. Quantifying the sourcesink balance and carbohydrate content in three tomato cultivars. Front. Plant Sci. 6(416):1-10.

Loescher, W., T. Roper, and J. Keller. 1986. Carbohydrate partitioning in sweet cherries. Proc. Washington State Hort. Assn. 81:240-248.

Marcelis, L.F.M. 1996. Sink strength as determinant of dry matter partitioning in the whole plant. J. Expt. Bot. 47:1281-1291.

Minchin, P.E.H., M.R. Thorpe, J.N. Wünsche, J.W. Palmer, and R.F. Picton. 1997. Carbon partitioning between apple fruits: short- and long-term response to availability of photosynthate. J. Expt. Bot. 48:1401-1406.

Moing, A. and J.P. Gaudillere. 1992. Carbon and nitrogen partitioning in peach/plum grafts. Tree Physiol. 10:81-92.

Nakano, R., K. Yonemori, and A. Sugiera. 1998. Fruit respiration for mantaining sink strength during final swell at growth stage III of persimmon fruit. J. Hort. Sci. Biotechnol. 73:341-346.

Pavel, E.W. and T.M. DeJong. 1993. Source and sink-limited growth period of developing peach fruits indicated by relative growth rate analysis. J. Amer. Soc. Hort. Sci. 118:820-824.

Reyes, F., T. DeJong, P. Franceschi, M. Tagliavini, and D. Gianelle. 2016. Maximum growth potential and periods of resource limitation in apple tree. Front. Plant Sci. 7(233):1-12.

Roper, T., J.D. Keller, W.H. Loescher, and C.R. Rom. 1988. Photosynthesis and carbohydrate partitioning in sweet cherry: Fruiting effects. Physiol. Plant. 72:42-47.

Roper, T., W. Loescher, J. Keller, and C. Rom. 1987. Sources of photosynthate for fruit growth in 'Bing' sweet cherry. J. Amer. Soc. Hort. Sci. 112:808-812.

Simkhada, E.P., Y. Sekozawa, S. Sugaya, and H. Gemma. 2007. Translocation and distribution of ${ }^{13} \mathrm{C}$-photosynthates in 'Fuyu' persimmon (Diospyros kaki) grafted onto different rootstocks. J. Food Agr. Environ. 5:184-189.

Teng, Y., F. Tamura, and K. Tanabe. 2002. Partitioning patterns of photosynthates from different shoot types in 'Nijisseiki' pear (Pyrus pyrifolia Nakai). J. Hort. Sci. Biotechnol. 77:758-765.

Teng, Y., K. Tanabe, F. Tamura, and A. Ohmae. 2001. Fate of photosythates from spur leaves of 'Nijisseiki' pear during the period of rapid fruit growth. J. Hort. Sci. Biotechnol. 76: 300-304.

Toldam-Andersen, T.B. 1998. The seasonal distribution of ${ }^{14} \mathrm{C}$ labelled photosynthates in sour cherry (Prunus cerasus). Acta Hort. 48:531-540 
Toselli, M., G. Marcolini, J. Flore, and L. Lombardini. 2014. Leaf assimilation, carbon translocation and root respiration in 'Budagovski 9' apple cuttings grown in low soil moisture condition. Eur. J. Hort. Sci. 79:241-247.

Vivin, P., F. Martin, and J.M. Guehl. 1996. Acquisition and within plant allocation of ${ }^{13} \mathrm{C}$ and ${ }^{15} \mathrm{~N}$ in $\mathrm{CO}_{2}$ enriched Quercus robur plants. Physiol. Plant. 98:89-96.

Wang, L.Q., F. Tang, J. Zhang, and H.R. Shu. 2003. Effect of dwarfing rootstock on carbohydrate transportation and distribution of apple. Acta Agriculturae Nucleatae Sinica 17:212-214.

Whiting, M.D. 2005. Physiological principles for growing premium fruit, p. 57-64. In: M.D. Whiting (ed.). Producing premium cherries: Pacific Northwest fruit school cherry short course proceedings. Good Fruit Grower Press, Yakima, WA.

Whiting, M.D. and G. Lang. 2004. 'Bing' sweet cherry on the dwarfing rootstock 'Gisela 5': Thinning affect fruit quality and vegetative growth but not net $\mathrm{CO}_{2}$ exchange. J. Amer. Soc. Hort. Sci. 129:407-415.

Wright, C.J. 1989. Interactions between vegetative and reproductive growth, p. 15-27. In: C.J. Wright (ed.). Manipulation of fruiting. Butterworths, London, UK.

Wünsche, J.N., D.H. Greer, W.A. Laing, and J.W. Palmer. 2005. Physiological and biochemical leaf and tree responses to crop level in apple. Tree Physiol. 25:1253-1263.

Zhang, C., K. Tanabe, F. Tamura, A. Itai, and S. Wang. 2005. Spur characteristics, fruit growth, and carbon partitioning in two late maturing Japanese pear (Pyrus pyrifolia Nakai.) cultivars con contrasting fruit size. J. Amer. Hort. Sci. 130:252-260.

Zhou, Y.Q., S.J. Qin, X.X. Ma, J.E. Zhang, P. Zhou, M. Sun, B.S. Wang, H.F. Zhou, and D.G. Lyu. 2015. Effect of interstocks on the photosynthetic characteristics and carbon distribution of young apple trees during the vigorous growth period of shoots. Eur. J. Hort. Sci. 80:296-305. 